CATALLAXY

Volume 5 Issue 2 December 2020

e-ISSN 2544-090X

C www.catallaxy.pl

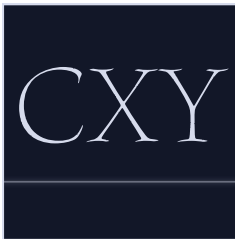

Original article

received: 10.11 .2020 / accepted: 15.12 .2020 / published online: 31.12 .2020

(ㄷ)(1)

Kacper Ochocki, K. (2020). The ability of excise duty to reduce market failures in Poland. Catallaxy, 5(2): 75-86. doi:10.24136/cxy.2020.007.

\title{
The ability of excise duty to reduce market failures in Poland
}

\author{
KACPER OCHOCKI \\ Wroctaw University of Economics and Business, ul. Komandorska 118/120, 53-345 Wroctaw, Poland \\ 曰ochockikacper@gmail.com \\ iD orcid.org/0000-0002-5694-7143
}

\begin{abstract}
Motivation: The modern economy shows many imperfections in its functioning that do not exist in the model conditions of perfect competition. These are the so-called market failures which prompted the state's activity in the markets. The subject of considerations in this paper is the ability of the excise duty to eliminate some of these imperfections. Aim: The main aim of the study is an attempt to answer the question whether on the beer market in Poland the declared objectives of the regulation are consistent with the achieved results on that market.

Materials and methods: To achieve the assumed goal, the analysis of the literature on the subject, legal acts and statistical data was used, and the problem was illustrated on the basis of a case study based on own research.

Results: The analyzes presented in this article on the regulation of the beer market in Poland may be helpful in supporting the hypothesis of inconsistent regulation of this market. In other words, the applied regulatory tool, which is the excise duty, does not lead to a decrease in the consumption of these goods, but causes other negative side effects.
\end{abstract}

Keywords: regulation; excise tax; market failures; beer market; tax efficiency

JEL: D04; D22; D60; K23; L51

\section{Introduction}

Alcoholic products belong to the group of products classified as stimulants. If abused, they can lead to negative health and social effects. They are not necessary for the human body, but individuals feel the need to consume them. Thus, in welfare economics, it is assumed that the state, guided by the public interest, should intervene in such a situation, because an unregulated market would lead to results that are not optimal from the point of view of social welfare.

This article considers the ability of excise duty to reduce some of the market failures in Poland. The analysis was based on one of the socially harmful goods, that is, in this work - beer. The main goal was to analyze the compliance of the declared objectives of the regulation with its actually achieved results. The article also aims to answer the question of how excise duty affects the functioning of this market and whether increasing its rates leads to the intended results. It is worth mentioning that the excise duty does not only play an important fiscal role for the state budget, and the legislator sets itself the task of reducing costs related to the consumption of goods harmful to health, as well as the negative effects associated with them.

The problem was illustrated on the basis of a case study which makes the hypothesis that 
the declared objectives of the regulation are inconsistent and actually achieved on the beer market. Section 2 introduces the basic concepts that can be used to analyze problems related to the effectiveness of excise duty. The theoretical background is briefly outlined the concepts of market regulation and imperfections of the market mechanism, which are the determinant of state intervention in the normative approach. Then, in Section 3, the methods and materials used are described. Section 4 contains the results of the research carried out. The study ends with the conclusions and summary of this analysis.

\section{Literature review}

\subsection{Market failure as a prerequisite for regulation: normative approach}

The causes of state regulation of markets and state intervention in the markets are related, inter alia, to with the failure of the market mechanism. The most common basic market failures include natural monopolies, public goods, externalities and imperfect information. This inefficiency may result from errors in the economic system and the entities operating in it (den Hertog, 1999, p. 224). The above-mentioned phenomena cause that the state of equilibrium towards which real markets are striving is far from the optimal state, in the sense of maximizing social welfare. The market is unable to deal with these failures and is unable to overcome their consequences. It can be assumed that market errors are not only deviations from the free market optimum, but above all permanent properties. Thus, the market is not a perfect optimization mechanism (Sadłowski, 2018, p. 170). The market states, described in neoclassical economics as market failures, are thus different from the Arrow-Debreu first best model of perfect competition. The theorem based on this model states that if the economy is composed of perfectly competitive markets, then the state of equilibrium is also the state in which the allocation of resources is Pareto optimal. This means that it is not possible to reallocate resources in such a way that it would be possible to improve the welfare of at least one person without worsening the welfare of another member of society (Borkowska, 2013a, p. 553).

Meeting the assumptions of perfect ordering is associated with high costs of free exchange protection and the costs of a perfect information system, called transaction costs. They were not taken into account in the perfect competition model, and are necessary to protect against unpredictability (Klimczak, 2006, p. 52).

Optimization, according to some economists, requires the regulatory action of the state consisting in the application of administrative and legal coercion (Fiedor, 2003, p. 29). Therefore, it is assumed that regulations are implied by market failures and the market's inability to create mechanisms leading to the optimal allocation of resources, which results in the loss of some social welfare ( $\mathrm{Ru}$ mianowska, 2010, p. 130). This approach is normative. It assumes that a fully informed regulator (state), which acts in the public interest, replaces the "invisible hand" in coordinating the interests of market actors in a way that allows for achieving an equilibrium comparable to the competitive optimum. Thus, the state acting in the public interest acts towards the optimal allocation of resources in the Pareto sense.

According to W.F. Samuelson \& S.G. Marx's (1998, pp. 598-599), microeconomic role of the state boils down, first of all, to the fulfillment of two essential functions: to regulate private markets where market failure may lead to ineffective production and / or consumption, and to make available the "appropriate" amount of certain public goods and services that private markets do not deliver at all or are unable to deliver the correct quantity. Thus, the starting point for further considerations is the recognition that market self-regulation leads to suboptimal, from the point of view of social welfare, results and market failures are a reason for state in- 
terference in economic processes (Levinson, 1992, pp. 13-14).

The above-presented approach that justifies the regulatory function of the state in economic relations is based on the assumption (usually implicite) that imperfection is a feature that characterizes the market, but not the state. As a result, information errors and transaction costs - which result in private actors not pursuing all the benefits that appear from market transactions - are disregarded in relation to the prescribed state action. It can therefore be concluded that as a result of government intervention, social welfare may be increased. The state, ex definitione, has full information on the social benefits and costs associated with the allocation of goods, and acting in the public interest, each time takes appropriate actions to correct market failures (Borkowska, 2009a, p. 250). In the literature, this line of reasoning (error of thought) is referred to as nirvana fallacy. Certain dangers arise from analyzing and assessing the economic reality based on a confrontation with a perfect model. Taking such a point of view (nirvana approach), one looks for differences between reality and the ideal, and finding deviations, the conclusion is drawn that economic processes are ineffective, and thus one succumbs to the "illusion of perfection" (Demsetz, 2002, p. 107). This view is typical of the traditional current of normative regulatory theory. It assumes that the state is benevolent, omnipotent and omniscient, thus idealizing the sphere of politics (Lipowski, 2002 , p. 176). Thanks to this, optimal regulation mechanisms can be built, in which, by focusing on the search for appropriate tools, the regulator can correct market failures and "restore" the efficiency of management in the sense of Pareto (Borkowska, 2009b, p. 28).

The starting point for normative concepts of regulation is therefore the claim that the market fails in two respects (Borkowska, 2013b, p. 201):

- in achieving the optimal allocation of social resources,
- in the implementation of social goals other than economic efficiency.

As a result, from the general concept of "regulation” defined by D. Spulber (1989, p. 267) as "general rules or specific actions imposed by administrative agencies that interfere directly with the market allocation mechanisms or indirectly by altering consumer and firm demand and supply decizions", taking due account of the subject of analysis in relation to the supply and demand sides of the market, it is possible and necessary to distinguish between economic regulation and social regulation.

Economic regulation consists of: structural regulation and conduct regulation (Kay \& Vickers, 1990, p. 233). The first is to control market entry and exit, and to establish and enforce rules for the provision of public services. The second relates to price control and the creation and enforcement of rules for minimum product quality standards and advertising. This division shows that economic regulation is identified with the state's activity in markets whose structure is conducive to restricting competition, such as natural monopolies (Borkowska, 2019, p. 212). In these areas, economic regulation is to be a substitute for free market principles (Ogus, 1994). The element of direct forcing to specific action distinguishes economic regulation from other instruments of the state's influence on the economy. Economic regulation mainly refers to the problem of the inefficiency of the competition mechanism (Walulik, 2013, p. 45).

Historically, a more recent type of regulation is social regulation (Viscusi et al., 1995, p. 307), which is sometimes contrasted with economic regulation. It should be emphasized that the scope of social regulation concerns a much wider group of state activities than the scope of economic regulation (Tenbücken, 2006, p. 68). Social regulation is the state's reaction to market imperfections consisting in a deficit of information on one of the parties to the contract or the occurrence of external effects (Ogus, 1994). It concerns the state's activities aimed at the protection of consumer rights, health protection or pro- 
tection of the natural environment (Surdej, 2011, pp. 27-28), as well as such matters as the safety of products purchased by consumers, working conditions, but also increasing the consumption of socially desirable goods. merit goods and the reduction of consumption of socially harmful goods (demerit goods). Thus, social regulation can be understood as an intervention of the state, which aims to provide socially desirable ways of using resources, protect entities from various types of risks related to functioning on the market, such as scarcity, unemployment or digital exclusion (Lipsey et al., 1988, p. 307). While in the case of economic regulation it seems possible to quantify the goal (e.g. the expected drop in prices), it is extremely difficult to determine when or to what extent a given goal has been achieved in the field of social regulation. This is because dispersed recipients are protected by social regulations. Their values valuable, but often inexpressible in money may be exposed to the actions of economic (commercial) entities (Surdej, 2014, p. 71).

\subsection{Social and economic effects}

The consequences related to the use of alcohol, and above all abuse, are observed in the sphere of biological, health and socio-economic phenomena. The negative economic effects of alcohol consumption include, first of all, macroeconomic losses in the form of state budget expenditure on health, social welfare and uniformed services. In addition, costs for insurance, social and charitable institutions that remove or reduce the economic and social impacts of alcohol, as well as losses for businesses, economic organizations and households. Health losses in the form of treatment and prophylaxis costs as well as the costs of preventing various social pathologies caused by alcohol consumption cannot be ignored (Barczak, 1993, p. 129).

\subsection{Legal conditions}

The Act on upbringing in sobriety and counteracting alcoholism (1982) was aimed at limiting alcohol consumption and changing the preferences of Poles. According to it, advertising and promotion of alcoholic beverages is prohibited in Poland. Beer advertising and promotion is excluded in this case. Other alcoholic beverages may be advertised, among others only inside wholesalers, separate stands or points selling alcoholic beverages in gastronomy. It is also forbidden to inform about sponsorship of mass events, including sports, music concerts and others, by producers of alcoholic beverages containing more than $18 \%$ alcohol. It is forbidden to sell and serve alcoholic beverages with a concentration greater than $18 \%$ in holiday homes and training centers. Depending on the percentage of alcohol (over 4.5\%), the points allowed for retail sale of these beverages are regulated, and the revenues from the license fees should be used to implement communal alcohol-prevention and problem-solving programs. These are just some of the restrictions contained in the Act.

Warnings about the harmfulness of alcohol are mandatory and their placement on alcoholic products is scrupulously followed by producers. However, in the conducted research, Poles declare a lack of awareness of the adverse health effects of consuming alcoholic beverages (Piekarz, 2019, p. 20). It should be mentioned here that a situation in which one type of alcohol is banned in public space and another is advertised in the media, both by celebrities, athletes or other people perceived as an authority in society, may suggest to the recipient that its harmfulness is relatively lower. There is also often a situation in which the recipients of advertising in the mass media believe that advertising products in the media means legal, but also state consent to use the product. Therefore, consent to advertise one type of alcohol may suggest that consumers are more acceptable to the state and society.

\subsection{The Act on excise duty}

The alcohol industry belongs to the type of activity which, due to the harmful effects of alcohol consumption on health, may evoke 
negative feelings. However, from an economic point of view, it is no different from any other activity. Like others, it brings benefits in terms of jobs and tax revenues. Taxes have existed for as long as the state has existed. Thanks to them, the state accumulates revenues that enable financing its activities, and therefore paying them is obligatory. Due to the subject of taxation, one can distinguish, among others indirect taxes, which are paid on the turnover of goods and services, including excise duty (Borkowska, 2016, p. 247).

Excise duty is imposed on selected goods, called excise goods, which include, among others, energy products, alcoholic beverages, tobacco products, raw tobacco, motor fuels, coal or animal fats and vegetable oils. The list of all excise goods is included in the appendix to the Act on excise duty (2008).

Goods subject to excise duty have changed over the years, starting from the period of transformation of the Polish economy, when the first act on indirect taxes entered into force. This was caused, inter alia, by the harmonization of the excise duty on certain products in the EU, which means common rules for the production, movement and storage of excise goods as well as for the assessment and collection of excise duty on these products. It was aimed at approximating the scope and level of rates in the Member States, as well as limiting tax competition between countries and not inhibiting the free movement of goods within the Community. The legal basis for this harmonization is Art. 113 of the Treaty on the Functioning of the European Union (2016).

Two reasons for imposing excise duty can be distinguished, which include (Chrupczalski, 2010; Kulicki, 2020):

- fiscal, aimed at increasing budget revenues, necessary to cover public needs;

- non-fiscal, which aims to reduce the consumption of specific groups of products using economic incentives and the production of goods that generate external costs.

It follows from the above that the purpose of the state, due to the excise duty, is not only to obtain revenues to the state budget to finance government expenditure for public purposes. Excise duty is one of the tools used to overcome market failures in two perspectives. The first is negative externalities. The second is based on the implementation of social goals, that is, limiting the demand for goods selected by the state due to their harmfulness to health and social disapproval (Borkowska, 2016, p. 248).

\section{Materials and methods}

The basis for considerations in the theoretical part was the literature on the subject, including both Polish and foreign-language publications, and legal acts. The title problem is illustrated on the basis of a case study. The analyzed empirical material comes from publicly available data, i.e. statistical yearbooks prepared by the Central Statistical Office (GUS, 2001-2019) or data from the European Commission (2020).

\section{Results}

The reason for the demand for a given good is the appearance of a need subjectively recognizable by given individuals and the simultaneous understanding that there is a good that will satisfy this need, even temporarily. If the price of a good is at a level that will allow a given need to be fully met, there is no reason to not satisfy it. According to the concept of a paternalistic state, the state knows better than the citizens what is good for them. This is related to the purpose of imposing the excise duty, namely to reduce the consumption of socially harmful goods, which include, inter alia, beer.

The consumption of alcoholic beverages in the years 1990-2018 changed. These changes were influenced by many conditions, such as the opening of borders and the related free movement of goods, trade liberalization or the introduction of new Western products to the Polish market. In the last 40 years, the tradition of drinking alcohol made vodka 
the most popular among Polish society. It was the most-bought alcohol until 1997, only to give way to beer in 1998. Currently, the beer market is responsible for the largest share of total alcohol consumption (58\%) (PARPA, 2019).

When confronting the consumption of beer per capita and the average retail price of beer (see Chart 1), it can be noticed that despite the decline in consumption in 2009-2010, its trend is growing. The temporary decline was caused by the global crisis and the excise tax increase in 2008 and 2009. Historically, in the 2000s, the lowest average price for a bottle of beer was in 2006 and amounted to PLN 2.59, and the highest in 2009, when it cost PLN 2.92. In 2018, a bottle of beer cost only $9.9 \%$ more than in 2000 .

A characteristic feature of the industry is the increase in consumption in the years when large sports events take place, such as the Football World Cup or the Olympic Games. The barrier of 99 liters per person was exceeded for the first time in 2012, when consumption increased by 5 liters per year. The demand for beer also grows when the air temperature rises.

As mentioned earlier, the main goal of the state's alcohol policy is to reduce the consumption of alcoholic beverages. In Article 10 of the Act on upbringing in sobriety and counteracting alcoholism (1982), it was stated that the prices of these drinks should be set at a level that would be ahead of the increase in income of the population. Therefore, the above-mentioned Act is supported by the Act on excise duty (2008). The amount of excise duty on beer in the years 2000-2020 is presented in Chart 2.

The presented data show that the excise duty rate on beer in Poland was increased 4 times in 20 years. It should also be mentioned that the excise duty rate on spirits was subject to changes six times. In 2003 it was even reduced from PLN 6,278 per 1 hectolitre of pure alcohol to PLN 4,400. The $10 \%$ increase in excise duty rates on all types of alcohol introduced from January 2020 maintains the privileges of spirits. As a result of the excise tax increase, the rate for beer increased by $53 \%$ over 20 years, while for spirits at the same time only by $4 \%$, which means that it fluctuates around the level in the years 2000-2001. In the case of beverages with a lower alcohol content, usually each excise duty increase is passed on in the price, and with strong alcohol it can be different, which results from the aforementioned reduction in the rate. The 2003 cut did not result in an overall drop in vodka prices. This meant that since then, producers had a kind of „bonus" in this tax in relation to other products. As a result, despite further excise tax increases, beer prices rose moderately. However, for 0.5 liters of vodka from 2003 you have to pay about PLN 20 (GUS, 2001-2019). In the price of a half-liter bottle of beer, the excise duty is approx. 0.50 PLN, while the VAT is approx. PLN 0.60 (Kalińska, 2017).

State budget revenues from the excise duty on beer (see Table 1) did not fluctuate significantly over the years, despite the increases in the rate, they are relatively stable. In the years 2008-2012 they grew systematically. In 2000, the state's income on this account amounted to PLN 1.77 billion, and in 2005, to PLN 2.62 billion (Zmarzłowski \& Orłowski, 2014, p. 307). This means that within 18 years the state budget revenues from excise duty on domestic beer products increased by $200 \%$. In 2018, they amounted to approximately PLN 3.6 billion, which accounted for $45 \%$ of the state's income from excise duty on spirits. Despite the increases in the excise tax rate, for the polar years it was by $14 \%$, the state's income on this account was constantly growing on average by $1.25 \%$. It is worth noting that in the last 10 years it has remained at the same level for the presented data. Interestingly, the excise tax increase resulted in an increase in budget revenues. Thus, it can be presumed that the price elasticity of beer demand is also inelastic. The currently applicable higher excise duty rate may cause, in terms of the planned revenues, effects similar to those in 2009, when budget revenues were twice lower than planned (Infor. Księgowość firm, 2019).

Many studies show that the price elasticity of alcohol demand is not zero, and the average 
result is -0.5 . The important fact is that it has different values depending on the type of alcohol. If the price of a given alcohol increases by $1 \%$, it will reduce beer consumption between $0.36 \%$ (Gallet, 2007, p. 124) and $0.46 \%$ (Waagenaar et al., 2009, p. 179). The situation is different in the case of strong alcohols, where a $1 \%$ increase in price results in a decrease in their consumption by $0.68 \%$ (Gallet, 2007, p. 124) and $0.8 \%$ (Waagenaar et al., 2009, p. 179). Therefore, it can be concluded that the consumption of vodka is the most sensitive to price increases. The research conducted by J. Wolak $(2015$, p. 217) in 2015 shows that the value of price elasticity is slightly greater than zero, amounting to $\varepsilon p=0,16^{1}$. The above data suggest that the increase in prices may bring financial benefits related to higher excise tax revenues. However, such a policy will not be effective in addressing the goal of reducing average consumption, as demand for alcohol is inelastic. Researchers note that the price control policy will have a greater impact on the level of consumption of strong alcohols than of beer (Ornstein \& Levy, 1983, p. 303). Moreover, a higher level of consumption per capita and a high share in the consumption structure are associated with reduced elasticity of demand (Fogarty, 2004, p. 29). Taking into account the high share of beer compared to consumption of other alcoholic beverages, the excise tax may not be effective. Moreover, the price elasticity of alcohol demand in addicts is lower than in other people. Therefore, it is likely that increasing the excise tax may not lead to a reduction in harmful consumption by addicts. In addition, in this situation, the tax costs are imposed on the brewing industry, which in the face of strong competition and high saturation of this market will take over part of the tax wedge against the fear of losing customers.

The effectiveness of fiscal actions depends on several factors, namely the possibility of substitution, the structure of alcohol consumption, local culture or the competitiveness of the local market and its saturation.

A similar result was also obtained in the work by Bielinska-Kwapisz \& Mielecka-Kubień (2011, pp. 1-13).
The alcohol market in Poland is dominated by the consumption of beer, which is relatively insensitive to the increase in excise duty compared to other alcoholic beverages. Preventive and educational activities on the harmfulness of alcohol seem to be effective among adolescents, but not among adults. A factor that could contribute to the reduction of alcohol consumption by Poles is the limitation of their physical availability, namely the reduction of the number of points of sale. Over the years, excise tax increases resulted in only a short-term decrease in consumption, and then beer consumption per capita returned to the level before the increase and increased.Beer affects human health in the same way as other alcoholic beverages, which are subject to numerous legal restrictions, and only beer can be widely advertised. It is also worth noting that non-alcoholic beer under the same brand names as those containing alcohol are a potential threat to minors, who may get used to this drink from an early age. In 2018, compared to the previous year, the increase in sales of bottles with beer with an alcohol content of up to $0.5 \%$ amounted to approx. $80 \%$ (Subik, 2019). Markets of alcoholic products have specific characteristics. On the one hand, the state budget receives revenues from their taxation, on the other hand, however, the state should limit the consumption of these goods. Thanks to the brewing industry, the state obtains approx. 4-5\% of all budget revenues, and in the excise duty revenues from alcohol alone they are on average around $20 \%$. Excise tax increases may turn out to be an unintended form of government support for the shadow economy at the expense of legal producers and honest consumers. At the same time, achieving the declared goals, i.e. limiting alcohol consumption, and thus reducing the harmful consequences of its consumption and related costs, seems uncertain.

\section{Conclusion}

The case studies are not intended to generalize, but only to substantiate hypotheses. Therefore, it seems that the analyzes presen- 
ted in this article, concerning the regulation of the beer market in Poland, may be helpful in supporting the hypothesis of inconsistency in the regulation of this market.

Due to the complexity of the institutional system, and in particular the enormity of the components, costs and goals achieved by changing institutions on the beer market, the process of optimizing the institutional structure is not and will not be fully controlled. Nevertheless, laws aimed at preventing the consumption of alcoholic beverages and protecting health against their consequences are not a priority for the legislator.

The functioning of markets is supposed to reduce the costs associated with a given category of goods. In such a situation, it can be argued that the regulatory tools used by the legislator lead to an increase in transaction costs in these markets, which is tantamount to a reduction in their prosperity. At the same time, it is difficult to approve the claim that these mechanisms increase the welfare of the whole society. It can therefore be argued that there is no consistency between the declared goals and the results achieved on the beer market.

The state's policy of limiting consumption and one of the instruments of its implementation, which is the Act on upbringing sobriety and counteracting alcoholism (1982), should eliminate negative trends on the alcohol market and develop it in a socially desirable direction. Already today, the provisions of the Act on upbringing in sobriety and counteracting alcoholism (1982) clearly indicate that the aim of the actions of state authorities is to limit harmful consumption of alcoholic beverages and to change the structure of their consumption. Looking at the current market trends and the consumption patterns of various types of alcohol in Poland, the need to achieve this goal is as relevant today as it was when the Act was drafted.

\section{References}

Act on excise duty [Ustawa $z$ dnia 6 grudnia $2008 \mathrm{r}$. o podatku akcyzowym] (Dz.U. $2009 \mathrm{nr} 3$ poz. 11) (Poland).
Act on upbringing in sobriety and counteracting alcoholism [Ustawa z dnia 26 października 1982 r. o wychowaniu $w$ trzeźwości i przeciwdziałaniu alkoholizmowi] (Dz.U. $1982 \mathrm{nr} 35$ poz. 230) (Poland).

Barczak, A. (1993). Ekonomiczne aspekty picia i nadużywania alkoholu. Alkoholizm i Narkomania, (1).

Bielińska-Kwapisz, A., \& Mielecka-Kubień, Z. (2011). Alcohol consumption and its adverse effects in Poland in years 1950-2005. Economics Research International. doi:10.1155/2011/870714.

Borkowska, B. (2009a). Niedoskonałości kontraktowania w trybie zamówień publicznych. Prace Naukowe Uniwersytetu Ekonomicznego we Wroclawiu, (497). doi:10.15611/pn.2017.497.17.

Borkowska, B. (2009b). Regulacja monopolu naturalnego w teorii i praktyce. Wrocław: Uniwersytet Ekonomiczny we Wrocławiu.

Borkowska, B. (2013a). Państwowa regulacja rynków. Przesłanki i skutki regulacji rynku papierosów w Polsce. Ekonomia i Prawo. Economics and Law, 12(4). doi:10.12775/eip.2013.040.

Borkowska, B. (2013b). Regulacja, wartości, ramy instytucjonalne. Ekonomia, 4(25).

Borkowska, B. (2016). Akcyza jako narzędzie korygowania zawodności rynku. In B. Borkowska (ed.), Mikroekonomia: studia przypadków. Wrocław: Uniwersytet Ekonomiczny we Wrocławiu.

Borkowska, B. (2019). Regulacja. In B. Borkowska, M. Klimczak, \& B. Klimczak (eds.), Ekonomia instytucjonalna. Wrocław: Uniwersytet Ekonomiczny we Wrocławiu.

Chrupczalski, S. (2010). Efekty zewnętrzne. Retrieved 12.02.2021 from https://www.nbportal.pl.

Demsetz, H. (2002). Information and efficiency: another viewpoint. In T. Cowen, \& E. Crampton (eds.), Market failure or success: the new debate. Cheltenham-Northampton: Edward Elgar.

den Hertog, J. (1999). General theories of regulation. In B. Bouckaert, \& G. de Geest (eds.), Encyclopedia of law and economics. Northampton: Edward Elgar.

European Commission. (2020). Tax receipts, alcoholic beverages, excise duty tables. Retrieved 28.06.2020 from https://ec.europa.eu.

Fal, A. (ed.) (2020). Alkohol w Polsce: kontekst społeczny, rynkowy $i$ legislacyjny. Retrieved 07.07.2020 from https://pracodawcyrp.pl. 
Fiedor, B. (2003). Działania zbiorowe w sferze zanieczyszczania środowiska i jego ochrony: próba objaśnienia na postawie teorii dóbr publicznych i teorii niedoskonałości rynku oraz teorii regulacji publicznej w gospodarce rynkowej. Prace Naukowe Akademii Ekonomicznej we Wroctawiu, (985).

Fogarty, J. (2004). The own-price elasticity of alcohol: a meta-analysis. Economics Discussion/Working Papers, (04-01).

Gallet, C.A. (2007). The demand for alcohol: a meta-analysis of elasticities. Australian Journal of Agricultural and Resource Economics, 51(2). doi:10.1111/j.1467-8489.2007.00365.x.

GUS. (2001-2019). Mały rocznik statystyczny Polski 2000-2018. Retrieved 06.07.2020 from https:// stat.gov.pl.

Infor. Księgowość firm. (2019). Akcyza na piwo 2020: będzie drożej niż $+10 \%$. Retrieved 06.07.2020 from https://ksiegowosc.infor.pl.

Kalińska, A. (2017). Rynek alkoholu w Polsce: 75\% ceny wódki to podatki. Retrieved 06.07.2020 from https://www.money.pl.

Kay, J., \& Vickers, J. (1990). Regulatory reform: an appraisal. In G. Majone (ed.), Deregulation or re-regulation: regulatory reform in Europe and the United States. London: Pinter.

Klimczak, B. (2006). Wybrane problemy i zastosowania ekonomii instytucjonalnej. Wrocław: Akademia Ekonomiczna im. Oskara Langego we Wrocławiu.

Kulicki, J. (2020). Podatek akcyzowy: leksykon budżetowy. Retrieved 12.02.2021 from http://www. sejm.gov.pl.

Levinson, M. (1992). Nie tylko wolny rynek: odrodzenie aktywnej polityki gospodarczej. Warszawa: PWE.

Lipowski, A. (2002). Ekonomiczna zawodność państwa: krytyczna analiza ujęcia antyetatystycznego. Ekonomista, (2).

Lipsey, R.G., Purvis, D.D., \& Steiner, P.O. (1988). Microeconomics, volume 1: Economics, New York: Harper and Row.

Ogus, A. (1994). Regulation: legal form and economic theory. Oxford: Clarendon Press.

Ornstein, S.I., \& Levy, D. (1983). Price and income elasticities of demand for alcoholic beverages. Recent Developments in Alcoholism, 1. doi:10.1007/978-1-4613-3617-4_18.

PARPA. (2019). Struktura spożycia napojów alkoholowych $w$ procentach $w$ przeliczeniu na $100 \%$ alkohol w latach 2000-2018. Retrieved 16.06.2020 from http://www.parpa.pl.
Piekarz, D. (2019). Pomiędzy PRL-em a III RP: prawne, społeczne $i$ kulturowe aspekty polityki alkoholowej $w$ Polsce. Retrieved from http://instytutstaszica.org.

Rumianowska, I. (2010). Normatywne a ekonomiczne ujęcie regulacji ekologicznych ze szczególnym uwzględnieniem roli grup interesu w ich kształtowaniu. Ekonomia i prawo. Economics and Law, 6(1). doi:10.12775/eip.2010.009.

Sadłowski, A. (2018). Przyczyny i ograniczenia interwencjonizmu państwowego $\mathrm{w}$ rolnictwie. Zeszyty Naukowe Państwowej Wyższej Szkoty Zawodowej w Ptocku. Nauki Ekonomiczne, 27.

Samuelson, W.F., \& Marks, S.G. (1998). Ekonomia menedżerska. Warszawa: PWE.

Spulber, D. (1989). Regulation and markets. Cambridge: MIT Press.

Subik, P. (2019). Pijemy coraz więcej piwa. Ponad 100 litrów na głowę. Retrieved 07.07.2020 from https://dziennikpolski24.pl.

Surdej, A. (2011). Nowoczesne państwo a gospodarka rynkowa. Retrieved from https://instytutobywatelski.pl.

Surdej, A. (2014). Regulacyjne instrumenty w polityce publicznej. Studia z Polityki Publicznej, 4(4). doi:10.33119/kszpp.2014.4.4.

Tenbücken, M. (2006). The regulation of network infrastructures in the new European Union: regime similarity after two decades of reform. Doctoral dissertation, Universität Konstanz.

Treaty on the Functioning of the European Union (OJ C 202, 7.6.2016).

Viscusi, W.K., Vernon, J.M., \& Harrington Jr., J.E. (1995). Economics of regulation and antitrust. Cambridge: MIT Press.

Waagenaar, A.C., Salois, M.J., \& Komro, K.A. (2009). Effects of beverage alcohol price and tax levels on drinking: a meta-analysis of 1003 estimates from 112 studies. Addition, 104(2). doi:10.1111/j.1360-0443.2008.02438.x.

Walulik, J. (2013). Reforma regulacyjna: przykład transport lotniczego. Warszawa: Instytut Wydawniczy EuroPrawo.

Wolak, J. (2015). Popyt na alkohol w Polsce: wyniki estymacji modelu QUAIDS. Metody Ilościowe w Badaniach Ekonomicznych, 16(4).

Zmarzłowski, K., \& Orłowski, A. (2014). Podatek akcyzowy z wyrobów alkoholowych jako źródło finansowania budżetu państwa w latach 1999-2012. Roczniki Naukowe Stowarzyszenia Ekonomistów Rolnictwa i Agrobiznesu, 16(2). 
Acknowledgements

Author contributions: author have given approval to the final version of the article.

Funding: this research was fully funded by the author's own sources. 
Appendix

Table 1.

Revenues from the excise duty on beer in 2008-2018 (in billion PLN)

\begin{tabular}{|c|c|c|c|c|c|c|c|c|c|c|c|}
\hline Year & 2008 & 2009 & 2010 & 2011 & 2012 & 2013 & 2014 & 2015 & 2016 & 2017 & 2018 \\
\hline revenues & 2.98 & 3.18 & 3.30 & 3.42 & 3.58 & 3.50 & 3.57 & 3.61 & 3.61 & 3.45 & 3.55 \\
\hline
\end{tabular}

Source: Own preparation based on European Commission (2020).

Chart 1.

Beer consumption per capita (in lit.) and the average retail price of light, whole, bottled beer (in PLN) in Poland in 2000-2018

120

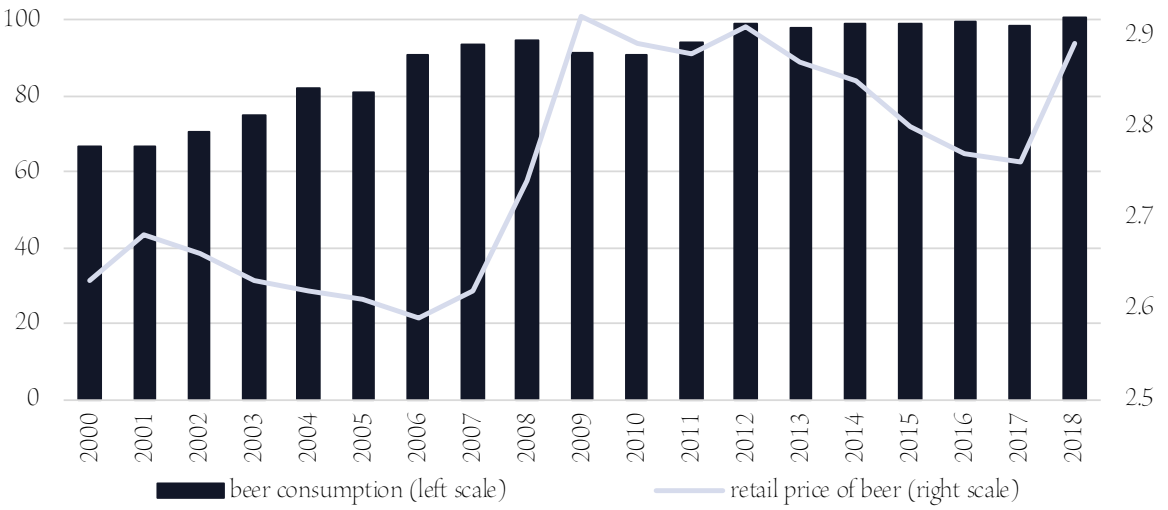

Source: Own preparation based on GUS (2001-2019). 
Chart 2.

The excise duty rate on beer in Poland in the years 2000-2020 per $1 \mathrm{hl}$ (in PLN)

9

8

7

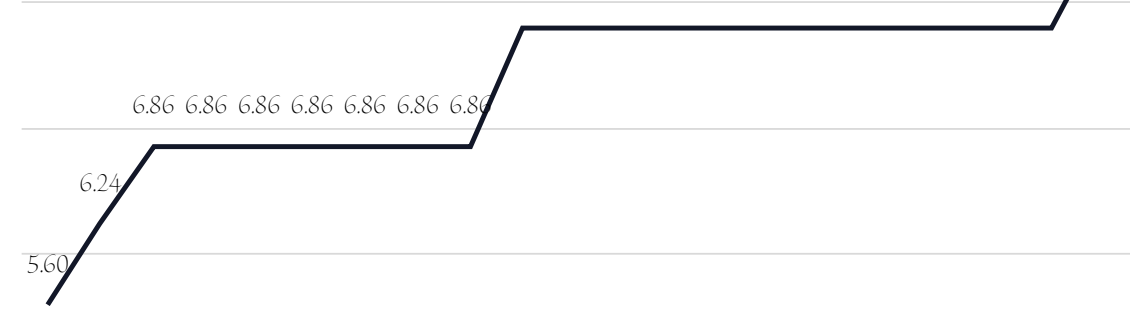

5

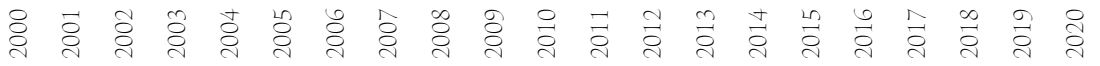

Source: Own preparation based on Fal (2020, p. 40). 